\title{
From Moscow with Love: Soviet Cultural Politics across India in the Cold War
}

Gautam Chakrabarti

Postdoctoral Researcher, ERC-Project “Developing Theatre," LudwigMaximilians-Universität, München, Germany; Freie Universität, Berlin, Germany

E-Mail: gchakrabarti@zedat.fu-berlin.de.

ORCID IDENTIFIER: //orcid.org/0000-0002-9466-5518

Biographical Note: Gautam Chakrabarti is a Postdoctoral Researcher with the ERCSub-Project “Learning 'the Moscow Rules': Theatre Artists from Postcolonial India in the Eastern Bloc, 1950-80,” at the Ludwig-Maximilians-Universität, a Lecturer at the Freie Universität Berlin, where he was a Dahlem Research School Honors Postdoctoral Fellow (2014-15) with the project “'Non-Committal Involvements': Literary Detectives and Cold Warriors across Eurasia.” He also served as a Global Humanities Junior Research and Teaching Fellow at The Hebrew University of Jerusalem. His PhD “Familiarising the Exotic: Introducing European Drama in Early Modern India” (201114) is currently in preparation as a book manuscript.

\section{From Moscow with Love: Soviet Cultural Politics across India in the Cold War}

\begin{abstract}
One of the less researched aspects of postcolonial India's "progressive" culture is its Soviet connection. Starting in the 1950s and consolidating in the '60s, the
\end{abstract}


Union of Soviet Socialist Republics (USSR) invested in building up “committed” networks amongst writers, directors, actors and other theatre- and film-practitioners across India. Thus, an entire generation of cultural professionals was initiated into the anti-colonial solidarity of emerging Afro-Asian nations that were seen, and portrayed, by the Soviets as being victims of "Western" imperialism. The aspirational figure of the New Soviet Man was celebrated within the framework of the rise of a new form of “transactional sociality” (Westlund 2003). This paper looks at selected cases of cultural diplomacy — through the lens of cultural history—between the USSR and India for two decades after India’s Independence, exploring the possibility of theorizing it from the perspective of an anti-colonial cultural solidarity that allowed agency to Indian interlocutors.

Keywords: Indo-Soviet ties, cultural Cold War, delegation-diplomacy, theaterand film-history

\section{From Moscow with Love: Soviet Cultural Politics across India in the Cold War}

Post-Independence India was one of the key sites where the "cultural Cold War” was fought, more often than not with as much gusto and ruthlessness as its ideological and military counterparts. ${ }^{1}$ Starting already in the 1950s and consolidating in the '60s, the Union of Soviet Socialist Republics (USSR) invested time, financial resources and organizational energy in building up “committed” networks amongst writers, filmmakers, theater-directors and other theater-personnel, stage- and screen-actors, musicians, dancers and other cultural professionals in various Indian cities. This Soviet strategy was followed and replicated by the German Democratic Republic (GDR) and other Eastern Bloc States, which acted almost as proxies. The Soviet approach was

1 Saunders, Cultural Cold War. 
characterized by a willingness — born, partially, out of need — to cut through the preexisting networks of cultural exchange between Anglophone and Europhone sociopolitical constellations and the enmeshed frameworks of colonial modernity that obtained amongst India's elites. ${ }^{2}$ Thus, an entire generation of theater-professionals and -activists was initiated into the anti-colonial solidarity of emerging Afro-Asian nations that were seen, and portrayed, by the Soviets as being victims of "Western" imperialism. The "New Soviet Man,”3 an ideational and even aspirational template that

2 One notes the emergence of two discursive strands in the debates on what has been termed —not without challenge— “colonial modernity": that of the colonial/imperial agency in introducing different aspects of modernity through Africa and Asia and the role played by indigenous structures and discourses in constructing a "model of truncated universals and subaltern fulfilment” based on the partial applications of universalist conceptual frames. See Moyn, "Nonglobalization of Ideas," 192. The selective nature of these appropriations is referred to by Partha Chatterjee thus: "Modernity for us is like a supermarket of foreign goods, displayed on the shelves: pay up and take away what you like.” Chatterjee, Our Modernity, 20.

3 Here, it should be pointed out that, amongst Soviet dissidents like the sociologist Aleksandr Zinovyev, who wrote Homo Sovieticus (1981, available in samizdat since the 1970s), the concept occasioned critical deconstruction of the Soviet reality and even sarcasm. This, of course, militated against the "dream or fantasy of utopias realized or imminent” that characterised the buoyant image the USSR, as well as the "West," sought to project in the three decades after WW2. See Madhavan Palat, Utopia and Dystopia, 5. As Palat notes, '[w]hile the post-colonial world suffered the limitless horrors of wars of liberation, famine, hunger and disease, and proxy civil wars... [d]uring these trenteglorieuses, the three decades of post-war recovery and prosperity... Nikita Khrushchev declared at the $21^{\text {st }}$ Party Congress in 1959 that the Soviet Union had entered 'the period of the full-scale construction of communist society."” Ibid. 
found resonance and acceptance-ranging from cautious to eager-throughout leftleaning cultural circles in postcolonial India, was celebrated within the framework of the rise of a new form of transactional sociality in Olle Westlund's definition, even a new humanity. ${ }^{4}$ The cultural policies of the USSR sought vigorously to encourage this trend and facilitate its links with parallel trajectories throughout Africa and Asia. Indian acteurs, in the fields of culture and politics, participated enthusiastically in what they saw as a defining struggle for equality and justice, as foregrounded by Soviet rhetoric, in the unstable and multi-layered cultural geographies of global power politics. Despite India's declared and steadfast commitment to the ideal of non-alignment, there can be little doubt that Soviet and Eastern Bloc engagement in cultural and, especially, theatrical activities in India was substantial and far-reaching. ${ }^{5}$

This involvement took various forms, but chief among them were the building of training programs for Indian theater-professionals and guidance regarding Brechtian and other "progressive” dramaturgical techniques. While the Soviets focused on training young theater-artists, the GDR offered Brechtian expertise through members of the Berliner Ensemble and charismatic directors like Fritz Bennewitz, who first visited and stayed in India in 1970 and continued to come till $1994 .{ }^{6}$ Bennewitz seems to have been a charismatic and inspiring theater-pedagogue and -director, who left an indelible

$4 \quad$ Westlund, S(t)imulating a Social Psychology.

5 The Non-Aligned Movement (NAM) is a bloc of largely postcolonial countries, almost entirely in the Global South, that sought, in the heyday of the Cold War, to maintain a neutral stance towards the two superpowers and their strategic constellations. Even during the Indira-Gandhi-years, during which the USSR became India’s biggest military backer, the NAM remained a cornerstone of Indian foreign policy; India even hosted a Summit in New Delhi in 1983.

${ }^{6}$ Esleben and John, Fritz Bennewitz in India, 297. 
impression on the hearts and minds of the young students, mainly associated with the National School of Drama (NSD), New Delhi. As K. V. Akshara, one of contemporary India's most respected theater-directors, who manages the NiNaSam, ${ }^{7}$ a multidimensional Indian cultural collective that focuses on non-urban theater says,

[w]e live today, in 2017, in a... largely different world; the world, the political world of the 1970s is gone. The times when... Bennewitz would work with us, with simple material, in a very complex way, engaged with [the] text, is also gone. We... have now entered an era of entertainment industry, where we have to cater to the tastes of the public or whatever we imagine in that name $[s i c]$. [...] In this new, difficult, strange world, the memory of Bennewitz helps me a lot and that is... the main reason I have kept the memories of Bennewitz intact within myself. And I am very happy that I had the privilege of working with him. ${ }^{8}$

It appears, from the above statement, that Bennewitz's appeal, reinforced by his pedagogic techniques, was based on his ability and willingness to present an alternative paradigm of cultural production to his students. This could be, as Akshara says elsewhere in his video-presentation, through “[Bennewitz’s] very interesting rehearsal techniques... [like] mak[ing] actors do their roles... in their own languages." ${ }^{9}$ He sought to privilege peripheral linguistic and cognitive-cultural registers, even if these were way outside his directorial comfort zone. This seems to have been "a specifically

7 For more information about the NiNaSam (Sri NIlakanteshwara NAtyaseva SAMgha): http://www.ninasam.org/.

8 This quotation comes from a video-presentation Indian Theater Artists and the Cold War prepared by Akshara for the International Workshop "Between 'East' and 'West': Indian Theatre Artists and the Cold War” (https://gth.hypotheses.org/375), held at the India International Centre, New Delhi, $29^{\text {th }}-30^{\text {th }}$ September, 2017. The clip can be viewed on the website of the ERC-Project "Developing Theatre" (http://www.developingtheatre.theaterwissenschaft.uni-muenchen.de/about us/index.html) on the URL: $<$ http://www.developingtheatre.theaterwissenschaft.uni-muenchen.de/ publications/media/workshop/index.html>, retrieved on $7^{\text {th }}$ December, 2018.

${ }^{9}$ Akshara, ibid. 
Bennewitzian contribution to interculturalism, because most other theater-directors who [...] did interculturalism at that point of time either ignored the language completely [...] or completely relied on other people to deal with the language.” ${ }^{10}$ It stands to reason that this may have reflected a core concern of Eastern Bloc cultural politics: the need to take a more solidarity-oriented approach to Afro-Asian societal-cultural specificities. Bennewitz’s own experiences and pedagogic and directorial strategies in India demonstrate a willingness, even urgency to reach out to voices that seemed, to him, subaltern. ${ }^{11}$ Similarly, the macro-level strategic goal of Eastern Bloc societalcultural networking seems to have been to attract the emerging nations, who were keen to consolidate their anti-colonial struggles into real postcolonial emancipation, into those political-ideological and geo-strategic alternatives as were being developed in the Eastern Bloc. This gives rise to a couple of questions which guide the discussion in this paper, even though no answers, as such, have been sought:

1. Did Soviet and Eastern Bloc cultivation of young Afro-Asian "cultureworkers” and -enthusiasts follow lines of ideological “commitment” and, thus, lead to the formation of an exclusivist network ${ }^{12}$

$\overline{10}$ Ibid. In this context, “interculturalism” connotes "intercultural performance”, which "in general refers to performance/theater that consciously or intentionally incorporates elements of performing traditions from disparate cultures as an approach to artistic creation.” Chang, “Intercultural Performance,” 482.

Esleben and John, Fritz Bennewitz in India; Akshara, Indian Theater Artists.

12 The term "culture-workers” (alternatively “cultural workers”) is used here to refer primarily to the Soviet and Soviet-Indian conceptualisation - from a Marxist perspective of cultural work as being the responsibility of a certain section of the social collective; the culture-worker is, thus, an integral and organic part of the working classes. This is a rather different understanding of cultural production from that which receives and deploys the term as solely 'refer[ing] to artists, writers, "worker-priests," media producers and other liminal individuals.' (Bernstein \& Connell, Traditions and Transitions, 279.) 
2. Did this transnational cultural-political investment reflect and/or nuance the USSR's understanding of India's diplomatic and strategic significance to the Eastern Bloc in the Cold War?

In response to such questions, my discussion attempts to engage with these involvements and network-formations through the consideration of a few selected cases of, primarily, Soviet delegation-diplomacy and political-ideological investments in the field of Indian culture, especially theater and film. Rather than attempt to theorize the Cold-War-era geopolitical spatialization of Eurasian cultural geographies as a reactive and subversive function to Eastern Bloc conceptualizations of colonial modernity, one juxtaposes the latter with the historical development of post/colonial institutions. However, it should be useful to discuss how this particular case is linked with transnational flows and can be approached through the prism of a general cultural circulatory model. ${ }^{13}$ In fact, one might even propose a "Black Sea” model of culturalpolitical circulation between the continental European metropolitan centers of the USSR and its Central and East Asian republics, which were the Soviet pivots to various Asian countries, India not least among them. ${ }^{14}$ This should be of assistance to the attempts to

13 A “cultural circulatory model” (CCM) is a concept inspired by the climatological framework called the "general circulation model" (GCM). GCMs are, to a large extent, based on extensive mathematical modelling of the circulatory patterns of the Earth's atmosphere and its ocean-systems. In the domain of Culture Studies, one could use CCMs to trace and map patterns of transnational and trans-local cultural flows and exchanges between metropolitan centers and borderlands. $C f$., the URL: <https://celebrating200years.noaa.gov/breakthroughs/climate model/welcome.html>, retrieved on $16^{\text {th }}$ December, 2017.

14 This conceptual suggestion is inspired by and hopes to link with Paul Gilroy's framingin terms of trans-cultural exchanges and hierarchies — of "[t]he Black Atlantic as a [c]ounterculture of [m]odernity." Gilroy, Black Atlantic, 1-40. The "Black Sea” trope was originally suggested to the present author by Louise Bethlehem, during a research-stay as a Visiting Fellow in her ERC-Project APARTHEID-STOPS. This multivalent concept, like Bethlehem's paradigms of the "restlessness" of apartheid and the "global itinerary" of anti- 
theorize the specificities—ideological rather than historical or ontological—of IndoSoviet cultural-political ties. Notions of a shared constituency of political-ideological values and structures and mutually-reflexive solidarity seem to be foregrounded in these contextual particularities. The diasporic frameworks of solidarity and intercultural dialogue, which are more useful in the study of India's relations with Anglophone countries, especially Britain and the United States of America (USA), presuppose a gradient of societal-political values and hierarchies that can be traced back to their colonial origins. Besides, as one of the stated bases and fundamental ideological premises of Soviet diplomacy in Afro-Asian countries was that of anti-colonial and imperial solidarity, it was strategic for the USSR to bypass the older patterns of societalcultural influence and control, as practiced by the former colonial powers. While the USA did not share this colonial access to the hearts and minds of Afro-Asian subjects and their diasporae in Europe's metropolitan centers and "the British distrusted the [American] application of general principles to complex colonial problems”, "the Anglo-American 'special relationship'” prevented the Americans from taking clear stands in keeping with their stated belief in "the inherent right [of colonial subjects] to become independent and rule themselves.”15 This Anglo-American proximity, even “collusion,” allowed the USSR to acquire the mantle of a credible and consistent

apartheid expressive culture (see Bethlehem, “Restless Itineraries”), promises to facilitate the unravelling of the layered nature of cultural politics in the Cold War era, with specific reference in this case to Afro-Asian cultural-political contexts. While a detailed exploration of this trope is beyond the scope of this essay, it is worth noting the salience of a Black-Sea-model of cultural-political circulation for frameworks of postcolonial solidarity in the Global South, including the Non-Aligned Movement that had socialist undertones but sought to remain neutral between rival superpowers. For the status of India, see Kirasirova, "Sons of Muslims.” 
champion of postcolonial and anti-imperial solidarity in the emerging nation-states of the Afro-Asian world, especially those attempting to be non-aligned.

There is a need -25 years after the end of the Cold War (though some are talking of its rekindling)— to collect experiences of and responses to questions regarding the formation of expert networks, philanthropic and/or governmental interventions, and people-to-people contacts in India and other Afro-Asian countries between the 1950s and 1980s. It is also necessary to engage with the postcolonial eliteformations, which resulted due to the above factors, during the vicissitudes of the Cold War. Culture was one of the core areas in which this geopolitical struggle was played out between the 1950s and '80s, with a number of figures, both individual and collective/institutional, in the contemporary Indian culture-scene having gone through the rites de passage of ideological persuasion. Academic exploration of these political contestations and problematizations of cultural praxis, especially in the Indian context, have opened up larger horizons of possible inquiry. This paper seeks to look at selected (mainly) Indian and Soviet practitioners and witnesses of this fascinating history in the early decades — that is, the '50s and '60s—of their activities.

Unpacking these political-ideological complexities will involve studying and analyzing the competing and often contradictory cultural-political mobilizations of the USSR-led Eastern Bloc and the US-led “West,” while acknowledging the forbidding nature of the Soviet understanding "that revolutionary writers had to subordinate their art to politics.” ${ }^{16}$ Like Max Eastman, who edited the American pre-World-War-I magazine The Masses, which sought to assimilate "radical politics and cultural experimentation,” a number of Indian culture-workers were of the opinion "that 'instead of liberating the mind of man, the Bolshevik revolution locked it into a state's prison

16 Lasch, Agony of American Left, n.p. 
tighter than ever before. ${ }^{\prime 17}$ This criticism was to be seen among center-right, independent, humanist and (former) socialist writers and other public figures, like Nissim Ezekiel, K. K. Sinha and Jayaprakash Narayan, who as Joel Whitney reminds us, issued a statement on the occasion of the Soviet military intervention in Hungary as the honorary president of the Indian Congress for Cultural Freedom.

\begin{abstract}
"Russia has no right to be in Hungary. No one can question the right of the Hungarian or any other people, including the Indian people, to choose a Communist form of government, if they so desire.” Narayan continued, “That would be a domestic affair. But when a big power by armed intervention tries to impose in another country its own puppets in power, it no longer remains a domestic question but becomes an international issue of the highest importance.”18
\end{abstract}

In order to counter this adverse image of its authoritarian foreign policy, the USSR launched a number of literary-cultural offensives, spearheaded by a number of journals focusing on different aspects of Soviet life. The Советская литература (Soviet Literature) had two major versions: literature in Russian, in the original, and as translations into foreign languages like English, French, German, Spanish, Polish, Czech and Slovak. The Советская женщина (Soviet Woman) appeared in twelve languages, including Hindi (from 1957) and Bangla (from 1973). The foreign editions

17 Ibid.

Whitney, CIA Tricked Writers, n.p. The Congress for Cultural Freedom (CCF), founded in 1950, was a product of the multi-dimensional efforts of the USA's Central Intelligence Agency (CIA) to facilitate and consolidate-mainly through funding and networkinganti-communist cultural and intellectual advocacy throughout Europe, Asia and Africa. It started winding itself up after The New York Times, in April 1966, published a five-part series of investigative articles on the charter and practices of the CIA. This process was hastened by the revelations of the CIA's funding of numerous anti-communist and/or liberal—but not necessarily non-leftist or anti-Marxist—cultural institutions and cultureworkers worldwide in explosive reports in the American magazines Ramparts and The Saturday Evening Post. See Kramer, “Congress for Cultural Freedom,” 7. 
did not quite replicate the Russian original completely, but the important consideration was that they needed to reflect the same positions regarding Soviet life and culture; careful political-ideological uniformity was, thus, a sine qua non. The Советский Союз (literally, Soviet Union, but issued in India by the TASS ${ }^{19}$ and the Information Department of the USSR-Embassy as Soviet Land) was published between 1950 and 1991 in nineteen languages, including Hindi, Bangla and Urdu. It was preceded, in 1930-41 and 1949, by the CCCP на стройке (USSR in Construction). The Cnopm 8 CCCP (Sport in the USSR) was a supplement to the Soviet Union, published in 1963-91 in major European languages. The unidentified contributors to a secret CIA-dossier partially declassified in 2011, “The Soviets in India: Moscow’s Major Penetration Program,” seem impressed, even overwhelmed by the Soviet presence in India as of $1985 .{ }^{20}$ It suggests that

[t]he Soviets enjoy nearly unfettered access to the pages of Indian newspapers, largely through the efforts of the Soviet Information Department. [Sanitized] Moscow overtly and covertly placed more than 160,000 items (original articles plus replays), in the Indian press, widely regarded as the freest in the Third World. Access to Press Trust of India, the largest English language news service, has become so automatic that some Soviet officials have come to call it "Press TASS of India."21

The TACC ог телеграфное агентство Советского Союза (TASS or Telegraphic Agency of the Soviet Union) was established in 1925 and functioned as the nodal news agency of the USSR; it continues to operate in post-Soviet Russia. This quite informative document, an "Intelligence Assessment [...] Declassified in Part Sanitized Copy Approved for Release 2011/12/09 : CIA-RDP86T00586R0004004900077” dating back to December 1985 (GI 85-10315), is henceforth cited as CIA, Soviets in India; Online: < $\underline{\text { https://www.cia.gov/library/readingroom/docs/CIA- }}$

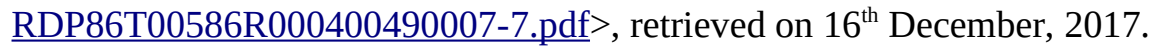
Ibid., iii. 
Although this document dates from the 1980s and is ideologically inflected, it does shed light on the extent to which the pioneering Soviet attempts at cultural diplomacy in the 1950s and '60s contributed to the perceived Soviet sociopolitical preponderance in India in the last decade-plus of the Cold War. Some (possibly inflated) estimates even spoke of "the Soviets fly[ing] in some 10 tons of propaganda material almost every day, for distribution in India’s major cities.”22 From the CIA-dossier and a number of newspaper- and magazine-articles in the mid-1980s, it appears that the USSR was widely perceived to be winning the “cultural Cold War” in, at least, India. The dossier, following Indian journalistic analyses, puts the Soviets "way ahead of the Americans” in their handling of "spin” and grass-roots networking with "the Indian news media”; the Russians are said to be "in touch with the masses, not with the elite." ${ }^{23}$ Nevertheless, what cannot be denied is the general lack of interest, in Indian society, for Soviet ideas of totalitarian governmentality and the USSR's problematic economic model, and its reservations about “Moscow’s poor track-record on human rights domestically and abroad."24

Thus, the visible and, to some, transparent étatiste orientation of Soviet cultural politics may have reduced the appeal of the USSR as a utopian topos of anti-imperial solidarity, while not affecting the pull and currency of Marxist and Communist interpretations of world affairs. While many Indian intellectuals, academics, artistes and other culture-workers appear to have given the USSR the benefit of the doubt, there was always a sense that the Soviets were not averse to fighting a proxy war against the USA on Indian soil. As stated in a Hindustan Times editorial on the sixth day after Mrs Indira Gandhi's assassination on $31^{\text {st }}$ October, 1984, "the Soviets had used the event as a

\footnotetext{
22 Chandra, “Soviets wage propaganda war,” n.p.

23 Ibid.

24 CIA, "Soviets in India," iv.
} 
'golden opportunity to mount cold war propaganda against the US [...]." ”25 Further, as US policy-makers—at least, the CIA — appear to have realized by the mid-1980s, "most Indians_-according to knowledgeable observers—-[were... not] sympathetic to Moscow’s political system.”26 However, more often than not, the Indian interlocutors of the USSR's various front organizations and representatives, in the areas of both cultural and people-to-people diplomacy, would find the Soviets “just like [them]” and "feel much more comfortable with the Russians." ${ }^{27}$ In fact, if the above-mentioned declassified CIA-dossier may be taken as a credible indicator of official American perception of Soviet influence within Indian society and government, the USSR does appear to have won the Cultural Cold War in India by the mid-'80s. The CIA-operatives and American diplomats working in India at the time seem to have felt that

[t]he broad range and sophistication of Soviet political influence efforts in India are unparalleled in the non-Communist Third World. Taken individually, each of the techniques employed — exploitation of Government and military ties, funding of political parties and politicians, use of front organizations, and, especially, the huge volume of propaganda and disinformation—yields both tangible and intangible advantages to the Soviets. [...] During the last decade and a half, they have had the cumulative effect of creating a climate in India that is receptive to and uncritical of many Soviet policy initiatives, and suspicious of Western—and particularly USinitiatives. ${ }^{28}$

In the absence of archival documentation and oral testimonies from the Soviet side it would not be fair to seek to call a winner in this tug of war between the superpowers in Cold-War-era India. This paper, instead of attempting such adjudication, focuses on the Indian experience of postcolonial solidarity-more claimed than actual—

\footnotetext{
25 Ibid., 9.

26 Ibid., 22.

27 Chandra, ibid., $\mathrm{n}$.pag.

28 CIA, “Soviets in India," 17.
} 
on the part of the USSR, and explores the extent to which Soviet funding- and pedagogic strategies produced results that might not have been readily identifiable with the stated ideological moorings of the USSR. This, in fact, seems to have been true across the ideological spectrum of the Cold War, with both the Americans and the Soviets striking deals, making alliances, funding individuals and collectives and achieving Realpolitik-results that belied the claimed societal-cultural values of the bloc in question. Thus, for example, despite being looked upon by their ideological critics as “elitist,” American institutions like the Ford Foundation routinely supported theaterand performance-projects that had a "grassroots" orientation. Conversely, the USSR and the rest of the Eastern Bloc did facilitate the creation, by the end of the '60s, of “committed” networks of "progressive” administrators, academics, performers and other artists who had begun to constitute the new elites of the Indian system of statesponsored and -administered cultural-political patronage. As the CIA-dossier notes and emphasizes repeatedly, "Soviet diplomats have extensive contacts with both cabinetlevel officials and the middle and upper levels of the various ministries of the central government in New Delhi." ${ }^{29}$ Though it accepts the lack of sufficient proof, it links this access to the increasing depth and range of Indo-Soviet ties.

Nevertheless, while the role of ideological and political commitments and adherences are of considerable significance in writing a history of Indian cultureworkers in/and the Cold War, one feels the need to also foreground the fact that Indian theorists and practitioners of cultural production—cutting across the societal-ideological spectrum—created all sorts of hybridized and liminally-constituted interpretations of "Western” and Soviet techniques and influences. It may even be suggested that this indicates a pattern of postcolonial "transcreation," to borrow a term from literary 
studies, of foreign literary, dramaturgical, cinematic and other artistic techniques and practices. ${ }^{30}$ More often than not, Indian culture-workers sought to develop themes and narratives that addressed specific Indian contexts and phenomena, even when ideological concerns might have necessitated certain formal or thematic choices and frames. Thus, it seems to have been possible to remain "rooted" while participating in the Kulturkampf of the Cold War. ${ }^{31}$ Though the cultural-political struggles of a nascent nation-state, as mediated through the prism of the Cold War, did not often make their way into the actual poems, novels, short stories, plays and films, issues of class struggle and subaltern suffering, as in the iconic Indian People’s Theater Association (IPTA)and Bohurupee-play Nabānna (New Harvest, 1944, 1948), were represented with an implicit and, occasionally, explicit acknowledgment of their international trajectories and repercussions. This seems to have led to a cultural-ideological co-constitution in Cold-War-era Indian cultural production within, at least, Soviet-Indian and other leftleaning constellations.

The multi-level utopian constructions that accompanied and were facilitated by the October Revolution, like, for example, the famous "utopian project of

30 The term "transcreation," which the writer, scholar, translator and publisher Purushottam Lal made salient, even famous, in the Indian literary-cultural context, is used here to approximate - in cultural adaptation - the Indian practice of what may be called creative translation. Thus, historically speaking, "when [Indians] admired a literary text in one language, [they] used it as a take-off point and composed a similar text in another language.” See Mukherjee, Transcreating Translation, 160. In the German-speaking world, the term Kulturkampf was originally used in the academic contexts, to refer to the long-haul conflict between the Prussian Kingdom, which transformed itself into the German Empire and the Roman Catholic Church. In the present context, it may be used to mean any conflict between societal-cultural frameworks that are seen, rightly or otherwise, to be locked in an existential struggle revolving around influence and hegemony. A good example would be the contemporary debates regarding the so-called "clash of civilizations," a phrase coined by Samuel P. Huntington. Huntington, Clash of Civilizations. 
electrification, condensed into an aphoristic utterance, [and] frequently reiterated by Lenin himself," became the new benchmarks of progressive thinking in India and other parts of the postcolonial world. Another ideological signifier was the soviet (council) that was the result of Lenin’s “vision of a self-organizing people governing themselves directly, the ancient dream of so many democrats who at various times used the model of the Greek polis, the Swiss cantons, and latterly American local democracy.” ${ }^{32}$ It appears to have been a defining feature of the political strategy of the Left Front, which had through successive electoral victories ruled the Indian State of West Bengal for 34 years, to exert a de facto societal-cultural control over the population through the institution of the "Local Committee," which could only have been inspired by the soviet-model. ${ }^{33}$ It may even be argued that there are a number of ways in which Jawaharlal Nehru, post-colonial India’s first Prime Minister, himself “always critical of the Indian Communists for their seeming imprisonment within the walls of $19^{\text {th }}$ century Marxism and for their unquestioning adherence to the Soviet example”, was not averse to radical utopianism himself. ${ }^{34}$ As someone with a disarmingly Romantic attitude to the Indian struggle for Independence, Nehru also subscribed to a form of "scientific

$32 \quad$ Palat, Utopia and Dystopia, 25; and 37.

33 The significance of the Local Committee of the Communist Party of India (Marxist) (CPI[M]) or "LC," as it was known colloquially in Left-Front-ruled West Bengal, is a good marker of what Tom Nossiter called the "Indian form of Communism.” Nossiter, Marxist state governments. The LC, which consisted of the leading local party-workers (or the "cadre"), was seen as a node of societal control at the level of the neighbourhood; often, it was invested with a forbidding or stabilising - depending on one's perspectiverole in informal local governance. These local party-workers often wielded hegemonic influence. See the description of such a Gräm Samsad (Village Parliament) meeting in West Bengal, attended by an LC, in Tenhunen and Karttunen, Contentious Connections, 119.

$34 \quad$ Gopal, “Formative Ideology of Nehru,” 789. 
socialist” utopianism in his thinking about India’s future. ${ }^{35}$ However, he saw his government's task as that of educating

the people so that they would be in a better position to decide when the issues came up. Then perhaps the socialist utopia would be attained, with the support of the vast majority and the least harm to anyone. [... Hence,] Nehru, although a radical in the European tradition, set out with confidence to work for this unprecedented, almost superhuman experiment of democratic socialism. ${ }^{36}$

This streak of utopian socialism in Nehruvian governmentality was one of the major contributory factors to "[t]he Indo-Soviet relationship [becoming] one of the Soviets' strongest with a non-Communist country” from modest if optimistic beginnings in the early '50s. ${ }^{37}$

\section{Chronology of Significant Cultural Events leading to the Indo-Soviet Special}

\section{Relationship}

In the Post-WW2 decades, the USSR was carefully, if with certain initial misgivings, exploring the terra incognita of Indian cultural life, clearly not understanding well enough what to expect. ${ }^{38}$ The first cultural contacts happened largely due to the personal agency and initiatives of a handful of prominent left-leaning public figures, like Khwaja

35 As evinced in his tour de force on what he saw as India's unbroken historical continuity, The Discovery of India (1946), Nehru's vision of postcolonial India was deeply influenced by his personal optimistic reading of Indian history.

36 Ibid.: 791.

37 CIA, “Soviets in India,” 1.

38 In fact, these seemed to persist till the very end of the Indo-Soviet saga and permeate the special relationship; certain sections of Soviet policy-makers seem to have felt that India was not a primary cultural-political destination. As Sergei Bratchikov argues, in his Candidate-of-Science (doctoral) dissertation, India was not considered interesting for and even worthy of exchanges in the domain of what the Soviets considered "high culture." Bratchikov, Soviet-Indian Relations, n.p. 
Ahmad Abbas (popularly known as K. A. Abbas, 1914-87), a prominent film-maker, author and journalist writing in Hindi, English and Urdu. His debut film Dharti kē Lāl (Children of the Earth, 1946) "was an explicit political movie with [...] a leftwing, radical cause.”39 Its producer was “the Indian People’s Theatre Association (IPTA), a theatre movement initially affiliated to the Communist Party of India, launched formally in Bombay in 1943, with its manifesto calling for a 'defense of culture against Imperialism and Fascism." "40 The film, which established Abbas's credentials as one of post-Independence India’s foremost proponents of cinematic socialist realism, was

set during the great Bengal Famine of 1943 that left five million dead despite the plentiful availability of grain, mainly through governmental callousness, [and] was based on Bijon Bhattacharya's landmark play Nabanna that inaugurated the radical theatre movement in Bengal. Despite a good harvest and rising grain prices during the war, they lose their property to a crooked grain-dealing landlord, and go to Calcutta along with thousands of similarly dispossessed peasants. Before dying, the patriarch enjoins his family to return to their native soil, where the farmers get together and, in a stridently celebratory socialist realist ending, opt for Soviet-style collective farming. ${ }^{41}$

In October 1947, S. M. Nanavati, a Bombay businessman, visited the USSR in a trade delegation and was impressed by different aspects of Soviet life; he also noted the considerable recovery the country had made within a couple of years after WW2. At a meeting organized by the local chapter of the Friends of the Soviet Union in Bombay on $3^{\text {rd }}$ April, 1948, he spoke in glowing terms about Soviet cultural policies and how the USSR valued and supported culture-workers. He waxed eloquent about what he saw as the preeminent position, both in popular and governmental spaces, of Soviet performers, who were said to be "worship[ed]" by the people. He also felt that Soviet "theatres and

\footnotetext{
39 Rajadhyaksha, Indian Cinema, 44.

40 Ibid.

$41 \quad$ Ibid., 44-5.
} 
operas are much better than those of the British and the Americans. [...] Their folk dances are very, very beautiful and they have wonderful festivals." ${ }^{22}$ There was a civil society movement, even a community that helped to establish, in the early '50s, an Organizing Committee to facilitate a Soviet Film Festival, with branches in Bombay and Calcutta, led by the then Chief Justice of the Bombay High Court, Mahommedali Currim (M. C.) Chagla (1900-81). Chagla was a staunchly secular, even atheist jurist who went on to become India's top diplomat in the USA and the UK and a Union Minister for Education and External Affairs in the '60s. Both Abbas and he, who appears to have been criticized for his open support to the USSR and his welcome address to the Soviet cinema-dignitaries Pudovkin and Cherkasov ${ }^{43}$ —more about whom hereafter-were instrumental in establishing bilateral Soviet-Indian frameworks of cultural exchange, which grew in direct proportion to the development of overall IndoSoviet ties.

After the first Moscow International Film festival (MIFF), which took place in February 1935, it would be more than two decades before the USSR was able to organize another similar event. ${ }^{44}$ It was only "during the liberal Thaw of 1959 ” that the next film festival took place, with its organizers even attempting to suppress the memory of the 1935-event. ${ }^{45}$ Though the traumatic ravages of WW2 and the scarring legacy of Stalin's tyranny had made Soviet film-makers rather incredulous of the feasibility of an international film festival in the USSR, the 1959-reinvention of the MIFF was made possible through the active engagement and support of the Soviet leadership. The initiative to trigger a discussion regarding the restarting of the MIFF

42 Vibhakar, A Model Relationship, 76, quoting from the Indo-Soviet Journal [Iscus]), Bombay, May 1948.

$43 \quad$ No author, Thought, n.p.

44 Fomin, "Moscow International Film Festival," 19.

$45 \quad$ Ibid., 27. 
was taken-in 1952, with the Cold War in full swing-by Ivan Bol'shakov, who was then at the forefront of Soviet cinema. The urgency with which his efforts achieved critical mass indicates the clear interest of the highest echelons of Soviet policy-making in the project, with "the Central Committee of the CPSU [giving] the permission to revive an international film festival in the Soviet capital” in $1958 .{ }^{46}$

Though the first post-WW2 MIFF could only take off in the end-'50s, the first Soviet film festivals, facilitated by the same agencies and individuals who were trying to organize the MIFF anew, were organized in Bombay and Calcutta in September 1950. This was followed at the end of that year, by the visit to India of a delegation of Soviet film-artistes, including the famous actor Nikolai Cherkasov (1903-66) and the renowned director and theorist Vsevolod I. Pudovkin (1893-1953), both People's Artists of the USSR (awarded in 1947 and '48, respectively) and favorites of Stalin. They traveled through a number of Indian cities and interacted with people from different social strata and professional backgrounds. They familiarized themselves with the historical and contemporaneous achievements of Indian literature, art, theater and cinema, and appeared to be considerably impressed by the artistic sensibilities of Indians. ${ }^{47}$ They were, as Cherkasov wrote in his travelogue, discussed later in this essay, quite impressed by what they perceived as the exotic aspects of life in India. However, they were also not unaware of the strategic cultural-political significance of a newlydecolonized India to the Soviet ideological project in the Afro-Asian world.

In the summer of 1953, a troupe of Indian dancers, singers and musicians visited the USSR. In August that year, an exhibition of Indian art, consisting primarily of reproductions of the frescoes of the Ajanta Caves and the sculptures at Ellora, Mughal and Rajput miniature paintings and a number of exemplars of modern Indian art, toured

\footnotetext{
$46 \quad$ Ibid., 26.

$47 \quad$ Thought, n.p.
} 
the Soviet land. The Indo-Soviet Cultural Society was set up on $14^{\text {th }}$ March, 1952, followed by the Society for Soviet Indian Cultural Relations on $24^{\text {th }}$ January, 1958. On $15^{\text {th }}$ January, 1954, a 31-member delegation of Soviet musicians and dancers including the world-famous ballerina Maya Plisetskaya, arrived in Bombay; it was headed by the then Deputy Minister of Culture Nikolai N. Bespalov. ${ }^{48}$ Cultural ties and explorations were being attempted in various other cultural and intellectual domains. A scientific delegation, headed by Academician Georgy F. Aleksandrov of the USSR Academy of Sciences, attended the $41^{\text {st }}$ session of the Indian Science Congress, which took place in Hyderabad from $2^{\text {nd }}$ to $7^{\text {th }}$ January, 1954. Prime Minister Nehru gave a special luncheon in honor of Aleksandrov, who was also the Soviet Minister of Culture and a Marxist philosopher, and the biologist Academician Vladimir A. Engelhardt. During one of the sessions, this delegation presented a representative collection of Russian books, which included translations of the Indian epics, the Mahābhārata and the Rāmāyaṇa, to the Congress; “[f]ifteen hundred guests of the Congress greeted this gift with an ovation.”49 Between $15^{\text {th }}$ and $26^{\text {th }}$ December, 1954, Ali Sardar Jafri (1913-2000), an Urdu poet, screen-lyricist, literary critic and occasional playwright for the IPTA, and the aforementioned K. A. Abbas visited Moscow to attend the Second Congress of Soviet Writers. Abbas was also there in the capacity of the leader of the Indian film-delegation,

For a rather "tragicomic" and ironically written account of this visit, for which Plisetskaya had been summoned to meet Bespalov in Autumn 1953, see the twenty-third chapter in her book, I, Maya Plisetskaya. Plisetskaya, et al., “My Trip to India,” 131. She observes, with the acerbic humor - mostly directed at the follies and foibles of Soviet apparatchikicharacteristic of the book, that “[a]fter Stalin’s death, the militant partisan Boris Ponomarenko was appointed [culture] minister. During the war, the partisan unit he led had bravely derailed German trains. The world of art was therefore right up his alley.” Ibid.

49 Engelhardt, Družeskije vstreči, 60. 
having written, directed and produced the first Indian song-free film, Munnā (Kiddo) that year; it was shown at the Edinburgh Film Festival and London.

In early 1956, the Indian Children's Art Exhibition was inaugurated in Moscow, and an Uzbek cultural delegation visited New Delhi. In September that year, an Indian educational delegation visited the USSR and, on $29^{\text {th }}$ October, Nehru inaugurated the "Public Education in the USSR" exhibition in Delhi. The burgeoning Soviet interest in Indian culture was also on display at the Indian Film Festival, which was held at the iconic Udarnik Cinema in Moscow in October '56. In December, the Soviet State Circus performed in Bombay, Madras, Calcutta and Delhi, before the establishment of the Soyuzgostsirk (Union State Circus) in 1957, with the proceeds from the ticket-sales being donated to the Indian Prime Minister's National Relief Fund. On $17^{\text {th }}$ October, 1965, an agreement was signed for the establishment of an Institute of Russian Studies in India, which was inaugurated on $14^{\text {th }}$ November that year. In 1969, it went to become the Centre of Russian Studies (CRS), the first academic unit of the renowned Jawaharlal Nehru University (JNU), New Delhi. ${ }^{50}$ Its establishment was, as the then Indian Union Education Minister, the aforementioned M. C. Chagla, put it, "a historic landmark in the history of education in [India]" and that of the growing cultural cooperation between the two countries. ${ }^{51}$ This cooperation was steered by the Soviet Ministry of Culture, which was the official patron of the Society for Cultural Relations (known, at present, as the Rossotrudnichestvo that is under the Russian Ministry of Foreign Affairs).

In spite of the growing momentum of, and bonhomie within, the Indo-Soviet relationship, along with a seemingly favorable cultural-political situation, the 1970s must be described as a rather disappointing period in terms of cultural exchange,

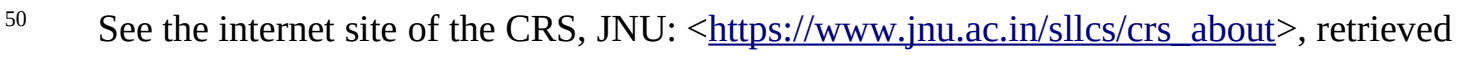
on $29^{\text {th }}$ December, 2017.

51 Ibid. 
especially given the potential and the genuine interest on both sides. It was only in the mid-'80s that the cultural traffic restarted, culminating in the Festival of Indo-Soviet Friendship, which was inaugurated on $3^{\text {rd }}$ July, 1987, at the Kremlin Palace of Congresses, by the Soviet General Secretary Mikhail Gorbachev and the Indian Prime Minister Rajiv Gandhi. The Indian inauguration of this Festival, on $21^{\text {st }}$ November, 1987, was an internationally televised event that was viewed by the present author on the State-run Indian TV-channel, Doordarshan. This author distinctly remembers the pomp and pageantry and the Indian media’s fascination with the culinary tastes of the Soviet First Lady, Raissa Gorbacheva.

It was towards the end of the USSR that these multi-dimensional official contacts and people-to-people engagements really blossomed into a special relationship, as the CIA-dossier discussed earlier in the essay testifies to. In the sphere of theatre and performance, in general, the two decades before the end of the USSR (1971-91) were full of productive exchanges, especially in ballet, choreography, folk dance and cinema. Though the main theater-groups were sent westwards, in 1982, the renowned Stanislavski and Nemirovich-Danchenko Musical Theater, which was usually sending ballet-troupes to India, toured the country for a month, with ticket-sales reaching 20,000. Indian folk-performers and dance-troupes were touring the USSR regularly. These genres, viewed as “peripheral,” were considered neutral in political-ideological terms and, therefore, appropriate in the context of the Soviet pivot to emerging AfroAsian countries. These engagements were popular enough to support rather than undermine Soviet self-conceptualization as a guarantor of fraternal international relations that were built upon the "friendship of peoples." 52 In the realm of cinema, the Soviets were more interested in buying low-grade Indian "Bollywood” films, which

52 Engerman, “Second World's Third World,” 185, 210-11. 
were clearly commercial, thus not allowing Indian art-house or any problem-oriented films to be released in theaters within the USSR. Though a number of Bollywood productions did focus on social issues with a realist lens, despite all the singing and dancing, this Soviet preference for Indian “entertainers” formed a very distinct image of mainstream Indian cinema in the USSR. ${ }^{53}$

It would not be an exaggeration to suggest that these cultural exchanges that had been going on for two-plus decades before the pivotal moment of $9^{\text {th }}$ August, 1971 when India and the USSR signed the Indo-Soviet Treaty of Peace, Friendship and Cooperation (ISTPFC) did function on both sides as attempts to evolve a broader geostrategic relationship. Apparently, the political and military aspects of the latter were to be predicated on cultural affinities and ideological proximity. The latter, however, centered not on the much-vaunted need, on the Soviet side, to establish socialist fraternity. The crux of the matter seems to have been an anti-colonial solidarity based on a broader postcolonial Afro-Asian rejection of those aspects of colonial modernity as were deemed to be rooted in the exploitative frameworks of Empire. The Soviets provided India with the possibility of cooperating with a superpower-with all the trade-related, military, diplomatic and technological benefits that entailed—without the cultural-ideological baggage of Empire and Colony that tainted the Anglo-American axis of influence to Indian policy-makers. As the two cases of Soviet cultural delegations discussed below should demonstrate, the USSR, despite its Europhilic cultural orientation, did take a fresh, if occasionally somewhat Orientalist and even naive, look at Indian cultural expression.

\section{Two Visits and Two Travelogues}

53 Rajagopalan, Leave Disco Dancer Alone!, n.p.; Bratchikov, ibid. 
Nikolai Cherkasov, who was one of Josef Stalin’s favorite actors, and Vsevolod Pudovkin, one of the most famous early-Soviet film directors, traveled to India on an official visit that had lasted 40 days, landing in Bombay on 31 $1^{\text {st }}$ December, 1950. ${ }^{54}$ Cherkasov's many and varied societal-cultural impressions were published, in the form of a short travelogue titled In India, in the USSR in the early '50s. These travelreminiscences, written in simple language, were an amateurish but palpably sincere attempt to encapsulate his impressions of the "fairy-tale land,"55 which was just beginning its life as an independent and unified nation-state. Indian cinema-goers were, at that period of time, discovering the world of international cinema and were able to attend the first Soviet film festival, which had started on $29^{\text {th }}$ September, 1950. The delegation, with Cherkasov and Pudovkin, made a week-plus-long journey, which was described by Cherkasov as almost an Odyssey-like voyage via Prague, Rome and Cairo. When they finally reached India they seem to have had the impression that Indian interest in Soviet cinema was already very pronounced, and that Cherkasov's was a well-known name. The entire group was officially invited by the Bombay and Calcutta Committees that were organizing the Soviet Film Festival. The aim was to augment and diversify, through such direct contacts, the Soviet cultural presence in India. The primary press-support for this visit was undertaken by pro-USSR media-outlets, such as

$54 \quad$ Pudovkin had, after youthful dalliances with non-mainstream acting and directing methods and strategies, decided to play it safe - for example, agreeing with "the application of Stanislavsky's theories on acting to cinema." Sargeant, "Vsevolod Pudovkin,” 31. He was a favourite of the Soviet Establishment due to his middle-path methodological conservatism. “[H]e was rewarded as Doyen of Cinematography” even before the renowned Sergei Eisenstein. Ibid.

55 Cherkasov, V Indii. Putevyje Zametki, n.p. This discussion of the visit is entirely based on Cherkasov's travelogue. All translations from Russian texts have been made by the author with the kind help of Dr Tatiana Dubyanskaya. 
Russy K. Karanjia’s hard-hitting tabloid Blitz, ${ }^{56}$ and K. A. Abbas in his personal capacity, together with a handful of activists and ideological fellow-travelers.

Despite these modest means, they managed to give the Soviet representatives a convincing impression that India was looking forward to cooperating with the USSR in the cultural domain, especially in film and theater. ${ }^{57}$ However, in spite of all this and as was neatly overlooked, “[b]etween 1950 and 1954, the audience for Soviet films in India averaged two thousand viewers per annum. Results were even more dismal in 1961 when nine Soviet film festivals held in India earned lower revenues than in preceding years. ${ }^{58}$ With Pudovkin passing away in 1953, Indo-Soviet cinematic coproduction could not take off in style before a number of years. It was left to K. A. Abbas to bring about an impressive Indo-Soviet co-production involving his Naya Sansar International and Mosfilm, with his film Pardesi (Foreigner) or Хождение за три моря (Journey Beyond Three Seas) in 1957. This film, well-received at the boxoffice, was co-directed by Abbas and Vasili M. Pronin, was made in both Hindi and Russian and had a mixed Indo-Soviet cast, with some well-known actors like Oleg Strizhenov, Nargis Dutt, Prithviraj Kapoor, Balraj Sahni, et al. ${ }^{59}$ The film had joint Indo-Soviet teams in all areas of production, including music and screenplay. It is possible to make the claim that it was the first and, apparently, the only Soviet attempt to export to India a cinematic image of a just, strong, free-spirited and confident (even proud) “New Soviet Man.” This was, however, in the form of the medieval commercial traveler Afanasi Nikitin, who had traveled through India (1466-72). Later on, in various

56 The Blitz has been described as being "radical and idealistic in views (with an unmistakable leftist and pro-Soviet orientation, which was the intellectual flavour of the time).” See Kulkarni, “He launched Blitz,” n.p.

57 Cherkasov, V Indii. Putevyje Zametki, n.p.

58 Rajagopalan, Taste for Indian Films, 144.

59 Mahmood, Kaleidoscope of Indian Cinema, 74. 
co-productions and other films, Indian film-makers opted for and Indian audiences seemed to be much more receptive to Soviet female characters and actresses. In this context, the most famous figure was Ksenia Ryabinkina who acted as “Marina,” a Soviet lead trapeze-artiste visiting an Indian circus, in Raj Kapoor’s Merā Nām Joker (My Name is Joker, 1970).

The Cherkasov-Pudovkin delegation visited a number of film studios in Bombay and Calcutta, met with film directors and cinematographers like Nemai Ghosh (191488), dancers and choreographers like Uday Shankar (1900-77), actors like Prithviraj Kapoor (1906-72), and people from other walks of life. They watched a number of films and a play in Calcutta at the famous Natyamandir Theatre of Sisir Kumar Bhaduri (1889-1959); made dozens of presentations; and even did spontaneous recitals. One of the perspectives that were prominent at the meetings and in the speeches and articles of both Soviet and Indian figures, including Mulk Raj Anand, Nalini Jayvant, Russy Karanjia and others, was the comparing and contrasting of the "warm, sincere and immensely humane” Soviet sensibility—in the words of a Blitz-editorial—with the "bad influence of Hollywood on Indian cinematography." ${ }^{60}$ It seems that, to Cherkasov, Indian performative culture, especially theater, was immature. He appears to have considered Indian cinema as being more growth-oriented and versatile and abreast with international developments than Indian theatre and dance. In his travelogue, he emphasized that the highest concentration of theaters in India-five-was in Calcutta. This was an unbelievably low figure when juxtaposed with the Soviet situation, as there were around 800 state-supported theaters in the USSR. ${ }^{61}$ In dance, he was on the lookout for “freshness” and "unpretentiousness,” which, for him, meant “unspoiled

\footnotetext{
60 Cherkasov, V Indii. Putevyje Zametki, n.p.

61 Ibid.
} 
people’s art.”62 Thus, the choreography of Uday Shankar seemed technically very accomplished to him, but artificial and excessively stylized, due to what Cherkasov saw as "the [apparent] demands of American agents and the tastes of a bourgeois audience.”3ㅜ What he lacked was a nuanced or even basic awareness of traditional Indian dance-forms, which constituted the bed-rock of Shankar's artistic expression. This was instrumental in his clear inability to understand Shankar's choreographic and thematic choices. Thus, as observed also elsewhere in this essay, official Soviet recognition of cultural norms and forms in India and elsewhere seems to have followed ideological paradigms and “guidelines.” More often than not, these adjudicatory frameworks reflected the general Soviet attitude, replete with its often hierarchical conceptualizations of "national” cultures, towards cultural relations with emerging Afro-Asian states; the USSR was, indeed, often not quite brotherly.

In 1957-58, another Soviet delegation — this time a small one with a more focused theatrical interest - toured India. It was led by Boris A. Babochkin (1904-75), another iconic face of Soviet cinema and theater, who was, in 1952-53, the Artistic Director of the Moscow Drama Theater Named after A. S. Pushkin. ${ }^{64}$ Babochkin's work was marked both by international acclaim after his eponymous role in the Soviet classic film Chapaev (1934) and difficult equations with, among others, Ekaterina Furtseva (1910-74), the long-standing Soviet Minister of Culture (1960-74). ${ }^{65}$ He seems to have been well-known in India, especially to K. A. Abbas and Balraj Sahni, ${ }^{66}$ the latter

62 Ibid.

63 Ibid.

64 In Russian, Московский драматический театр имени А. С. Пушкина. Online: URL http://teatrpushkin.ru/.

65 Scheglov, “Čapaem zaklejmlennyj,” n.p.

66 Balraj Sahni (1913-73), a charismatic Indian theatre- and film-actor, radio-announcer (for the BBC's Hindi Service) and writer (mainly in his mother-tongue Punjabi), was one of 
having met him in Moscow in $1956 .{ }^{67}$ His Indian sojourn, along with some other foreign trips, events that could, by no means, be taken for granted in the USSR, was described in his memoir, In Theater and Cinema. One of the first blanket statements, which he makes in the beginning of the chapter “Месяц в Индии” (“А Month in India”), is that there seems to be no professional theater in the country. ${ }^{68}$ There are, he writes, perhaps a dozen or a maximum of twenty professional theater-troupes in a country with a then population of 400 million people. However, he finds this to be compensated with what he sees as people’s art, amateur in principle, but very vibrant.

The sole stated purpose of this delegation of three-four people-he does not name the other members, saying only that he was "Number 3" - was to find out more about Indian theater. Babochkin is clearly impressed by the IPTA and its involvement with Indian culture, and wonders about the "heightened understanding of responsibility and internal discipline” in its ranks. ${ }^{69}$ He goes on to summarize the history of the IPTA, going back to the songs of peasants', workers' and other popular resistance. These songs were collected by Communist and other leftist stalwarts like the poet Nibaran Pandit who wrote the famous poem “Janajuddher Dāk” (“Call to People’s War”); ${ }^{70}$ the the key figures in the Indo-Soviet Cold-War-era cultural relationship. He won the Soviet Land Nehru Award for Merā Rusi Safarnāmā (My Russian Travelogue), which he wrote after his trip to the USSR in 1969. However, despite his ideological leaning, he was not a blind admirer of the Soviet cause and "made his own criticism of affairs and ways which he thought were not right.” Joshi, Intimate Portrait, 82.

Babochkin, $V$ teatre i kino, n.p.

Ibid.

69 Ibid.

70 This poem was widely known in the Bengali-speaking areas of India after being published, on $1^{\text {st }}$ July, 1942, in the newspaper Janajuddha (People’s War). The Communist activist and poet Nibaran Pandit (1912-84) had "attended the $1^{\text {st }}$ congress of the Communist Party of India as well as the $1^{\text {st }}$ conference of the IPTA[,] both in Mumbai[,] in the month of May, 1943. He got acquainted with the stalwarts of the then 
lyricist and musician Binoy Roy whose songs at the time of the Bengal Famine in 1943 "moved the countrymen to tears from Punjab to Maharashtra;",11 and the poet, dramatist, actor, musician and one-term parliamentarian Harindranath Chattopadhyay, ${ }^{72}$ among others. This corpus and the painstaking work behind it encouraged small groups of enthusiasts in many cities and towns throughout the length and breadth of India. Finally, Babochkin writes, their representatives met in Bombay, in 1943, to start the IPTA under the leadership of N. M. Joshi. By 1947, the IPTA consisted of 600 groups with thousands of members and became a grass-roots cultural organization.

It does appear, in the light of the above, that the USSR made a concerted effort to woo Indian public opinion in the 1950s and early '60s, when it was largely perceived to be winning the Cultural Cold War, especially in the emerging countries. ${ }^{73}$ This strategy was pursued through cultural delegations, small-group personal diplomacy initiatives, people-to-people contacts and ideological network-formation. Having considered Indo-Soviet cultural diplomacy both at the formal and semi-official levels through the first-hand Russian accounts of Cherkasov and Babochkin, it is difficult to deny that some of the key Soviet cultural figures saw Indian theater as lagging behind

Indian theater[,] film and music.” N. a., “Kobi Nibaran Pandit,” n.p..

71 Gupta, Salil Chowdhury's First Life, n.p.

72 Harindranath (1898-1990) was the younger brother of Virendranath Chattopadhyay (1880-1937), a militant organiser in the armed struggle for Indian Independence that began in the first decades of the $20^{\text {th }}$ century. Virendranath was a "persistently and steadfastly anti-imperialist” (Barooah, Indian Anti-Imperialist, 1) itinerant revolutionary and lived in Germany and the USSR, before being executed by the NKVD during Stalin's genocidal Great Terror (1936-38).

73 As F. C. Barghoorn wrote, reflecting American policy-makers' perceptions, in the '60s, ‘[i]t is in the underdeveloped countries” or “"poorly developed” countries, as Khrushchev in his public speech at the Twentieth Party Congress referred to' them, "that post-Stalin policy has secured its greatest successes.” Barghoorn, “Cultural Strategy,” 188. 
that of the USSR. However, as Babochkin's account proves, the Soviets appear to have seen, at least in Indian folk-idioms, the potential for the development of an aesthetics of cultural solidarity that could later, perhaps, be recalibrated in political-ideological terms. In this, the Soviet conceptualization of socialist modernity appears to have engaged with post-Independence India's own tryst with anti-colonial solidarity and its dissociation with what is often called colonial modernity. As Dipesh Chakrabarty writes, "shadows fall between the abstract values of modernity and the historical process through which the institutions of modernization came to be built." ${ }^{\text {74 }}$ India's postcolonial cultural history, especially in the domains of theater and cinema, appears to have negotiated these very interstitial shadow-lines that ran between and through the ideological borderlands of the Cold War. While Indian theater, even in the '70s, may not quite have “take[n] its cue from Moscow and East Berlin,”75 like Indian cinema, it did seem to find the cultural establishments of the USSR and Eastern Bloc countries responsive and even welcoming to the evolving idea of an Indian cultural modernity that solidarized with other Afro-Asian struggles against Empire and Colony.

Works Cited

Akshara. K.V. Indian Theatre Artists and the Cold War, 40 min., 20 sec. VideoPresentation for the ERC Workshop "Between 'East' and 'West': Indian Theatre Artists and the Cold War", 29-30 September, 2017, New Delhi, MPEG, http://www.developingtheatre.theaterwissenschaft.unimuenchen.de/publications/media/_ workshop/index.html. Accessed August 15, 2018).

Babochkin, Boris. V teatre i kino [In Theatre and Cinema]. Moscow: Vseros. teatr. Obvo “Iskusstvo,” 1968. https://www.libfox.ru/527593-boris-babochkin-vteatre-i-kino.html.

\footnotetext{
74 Chakrabarty, Habitations of Modernity, 80.

75 Sen, "Moscow and East Berlin,” n.p.
} 
Barghoorn, Frederick Charles. "Cultural Strategy in Asia, Africa, and Latin America.” In Soviet Cultural Offensive, 188-225. Princeton, NJ: Princeton University Press, 1960.

Barooah, Nirode K. Chatto: The Life and Times of an Indian Anti-Imperialist in Europe. New Delhi; Oxford: Oxford University Press, 2004.

Bernstein, CSJ, Eleanor, and Martin F. Connell, eds. Traditions and Transitions. Chicago: Liturgy Training Publications, 1998.

Bethlehem, Louise. "Restless Itineraries Antiapartheid Expressive Culture and Transnational Historiography.” Social Text 136 Vol. 36, no. 3 (2018): 47-69. https://doi.org/10.1215/01642472-6917766.

Bratchikov, Sergei. “Sovetsko-indijskije naučnyje i kulturnyje otnośenija v 1971-1991 gg. [Soviet-Indian Relations in Science and Culture between 1971 and 1991].” Candidate of Historical Sciences Dissertation. Moscow: Peoples’ Friendship U, 1995. http://cheloveknauka.com/sovetsko-indiyskie-nauchny-i-kulturnyeotnosheniya-v-1971-1 991 -gg

Chakrabarty, Dipesh. Habitations of Modernity. Essays in the Wake of Subaltern Studies. Chicago: University of Chicago Press, 2002.

Chandra, Prakash. “Soviets Wage Vigorous Propaganda War in India.” The Christian Science Monitor, January 18, 1982. https://www.csmonitor.com/1982/0118/011833.html.

Chang, Dongshin. “Intercultural Performance.” Encyclopedia of Case Study Research, 482-84. Thousand Oaks: SAGE Publications, Inc., 2010, https://doi.org/10.4135/9781412957397.

Chatterjee, Partha. Our Modernity. Rotterdam/Dakar: SEPHIS/CODESRIA, 1997. http://ccs.ukzn.ac.za/files/partha1.pdf.

Cherkasov, N. V Indii. Putevyje Zametki [In India. A Travelogue]. Moscow: Sovetskij Pisatel, 1952. http://www.universalinternetlibrary.ru/book/33742/ogl.shtml.

Engelhardt, Vladimir A. Družeskije vstreči sovetskih i indijskih učenyh [Friendly Meetings of Soviet and Indian Scientists]. Vestnik AN [Herald of the Academy of Sciences,] 10 (1954): 57-63.

Engerman, David C. “The Second World's Third World.” Kritika: Explorations in Russian and Eurasian History 12 no. 1 (2011): 183-211, doi:10.1353/kri.2011.0008. 
Esleben, Jörg, Rolf Rohmer, and David Gethin John. Fritz Bennewitz in India. Intercultural Theatre with Brecht and Shakespeare. Toronto: University of Toronto Press, 2016.

Fomin, Valerii. “The First International...: About the History of the Moscow International Film Festival.” Trans. Birgit Beumers. In Directory of World Cinema: RUSSIA 2, ed. B. Beumers, 19-27. Bristol, UK / Chicago, USA: Intellect Books, 2015.

Gilroy, Paul. The Black Atlantic: Modernity and Double Consciousness. Cambridge, Mass: Harvard University Press, 1995.

Gopal, S. “The Formative Ideology of Jawaharlal Nehru.” Economic and Political Weekly, 11 no. 21 (1976): 787-792.

Gupta, Samir K. Salil Chowdhury’s First Life and Mass Songs. Kolkata: S. K. Gupta / Basu Mudran, 2014.

Huntington, Samuel P. The Clash of Civilizations and the Remaking of World Order. New York: Simon \& Schuster, 1996.

Intelligence Assessment [...] Declassified in Part - Sanitized Copy Approved for Release 2011/12/09 : CIA-RDP86T00586R000400490007-7 (December 1985) GI 85-10315. https://www.cia.gov/library/readingroom/docs/CIARDP86T00586R000400490007-7.pdf (accessed December 16, 2017).

Joshi, Puran Chandra. Balraj Sahni: An Intimate Portrait. New Delhi: Vikas Publishing House, 1974.

Kirasirova, M. “'Sons of Muslims’ in Moscow: Soviet Central Asian Mediators to the Foreign East, 1955-1962.” Ab Imperio 2 no. 4 (2011): 106-132. doi:10.1353/imp.2011.0003.

“Kobi Nibaran Pandit - IPTA Shibpur (West Bengal).” https://sites.google.com/site/iptashibpurwestbengal/home/kobi-nibaran-pandit (accessed January 6, 2018).

Kramer, Hilton. "What was the Congress for Cultural Freedom?” The New Criterion. 8 no. 5 (1990): 7-13.

Kulkarni, Sudheendra. "He launched Blitz on Feb 1, died on Feb 1- it's no coincidence.” The Indian Express, February 2, 2008. archive.indianexpress.com/news/helaunched-blitz-on-feb-1-died-on-feb-1its-no-coincidence/268196/0 (accessed January 4, 2018). 
Lasch, Christopher. The Agony of the American Left. New York: Knopf Doubleday, 2013.

Louis, William Roger. “American anti-colonialism and the dissolution of the British Empire.” International Affairs, 613 (1985): 395-420, https://doi.org/10.2307/2618660.

Mahmood, Hameeduddin. The Kaleidoscope of Indian Cinema. New Delhi: Affiliated East-West Press, 1974.

Moyn, Samuel. “On the Nonglobalization of Ideas.” Global Intellectual History, ed. by Samuel Moyn and Andrew Sartori, 187-204. New York: Columbia University Press, 2013.

Mukherjee, Sujit. “Transcreating Translation.” Indian Literature 40, no. 4 (1997): 15867.

Nossiter, Tom. Marxist State Governments in India: Politics, Economics, and Society. London: Pinter Publishers, 1988.

Palat, Madhavan K. Utopia and Dystopia in Revolutionary Russia. Delhi: Ambedkar University of Delhi Press, 2017.

Plisetskaya, Maya, Antonina W. Bouis, and Tim Scholl. "My Trip to India." In I, Maya Plisetskaya, 131-38. New Haven, CT: Yale University Press, 2001.

Rajagopalan, Sudha. A Taste for Indian Films: Negotiating Cultural Boundaries in

Post-Stalinist Soviet Society. Bloomington, IN: Indiana University Press, 2005.

Rajagopalan, Sudha. Leave Disco Dancer Alone! Indian Cinema and Soviet MovieGoing after Stalin. New Delhi: Yoda Press, 2008.

Rajadhyaksha, Ashish. Indian Cinema : A Very Short Introduction. Oxford, UK: Oxford University Press, 2016.

Sargeant, Amy. “Vsevolod Pudovkin.” In Directory of World Cinema: RUSSIA 2, ed. B. Beumers, 19-27. Bristol, UK / Chicago, USA: Intellect Books, 2015.

Saunders, Frances Stonor. The Cultural Cold War: The CIA and the World of Arts and Letters. New York, NY: The New Press, 2015.

Scheglov, Dmitriy. “Čapaem zaklejmlennyj [Condemned by Chapay].” Soversenno Sekretno [Top Secret], 1 (176, January 1, 2004). http://www.sovsekretno.ru/articles/id/1135, (accessed January 4, 2018).

Sen, Asoke. "Indian Theatre Takes its Cue from Moscow and East Berlin.” The Stage, ed. by Peter Hepple, 12, (June 21, 1973). 
Tenhunen, Sirpa, and Klaus Karttunen, eds. Contentious Connections: Social Imagination in Globalizing South Asia. Newcastle upon Tyne: Cambridge Scholars Publishing, 2014.

Thought, Vol. 3. Delhi: Siddhartha Publications, 1951.

Vibhakar, Jagdish. A Model Relationship: 25 Years of Indo-Soviet Diplomatic Ties. New Delhi: Punjabi Publishers, 1972.

Westlund, Olle. S(t)imulating a Social Psychology: G. H. Mead and the Reality of the Social Object. Uppsala: Acta Universitatis Upsaliensis, 2003.

Whitney, Joel. Finks: How the CIA Tricked the World's Best Writers. New York: OR Books, 2017. In: The Wire, March 15, 2017, https://thewire.in/116189/ciasponsored-indian-magazines- engaged-indias-best-writers/ (accessed November 26, 2017).

Funding Details: The research (as a Visiting Fellow APARTHEID-STOPS) leading to these results has received funding from the European Research Council (ERC) under the European Union's Seventh Framework Programme (FP/2007-2013) / ERC Grant Agreement no. 615564. This work was also supported by the ERC-Advanced-GrantProject “Developing Theatre,” under the Grant Agreement No. 694559. 
